\title{
Assessment of Green Consumerism on Environmental Sustainability
}

\author{
Shreya Sangwan * and Rekha Vyas \\ Department of Resource Management and Consumer Sciences, College of Community and \\ Applied Sciences, Maharana Pratap University of Agriculture and Technology, \\ Udaipur, India \\ *Corresponding author
}

\section{A B S T R A C T}

\section{Keywords}

Green

consumerism,

Environmental

sustainability,

Knowledge,

Attitude, Practice,

Urban consumers

Article Info

Accepted:

28 September 2020

Available Online:

10 October 2020
Degradation of environment and natural resources is happening at a rapid pace. The consequences like climate change, global warming, and major catastrophes are appearing. Industries are one of the major sections that contribute in enormous amounts to deterioration of the environment. Environmental impacts are the untoward outgrowth of substandard economic activities. After looking at the current scenario, thought was given to take a study on the notion of assessing consumer's knowledge, attitude and practice towards green consumerism and environmental sustainability and making consumers deterrent towards the hazards of using non eco-friendly products. The present study was conducted on 120 urban consumers selected randomly and questionnaire method was used to collect data. Also, frequency, percentage and correlation were used for the analysis. Findings revealed that majority of the respondents had knowledge about green consumerism. Their attitude towards green consumerism and environmental protection was positive but the factor that restricted consumers from buying green products was the price, availability and lack of accurate knowledge about green consumerism.

\section{Introduction}

Today we are faced with an array of environmental problems, which together indicate a change in the ecosystem caused by human activities and challenge our present lifestyles. Environmental sustainability has received immense academic and industrial attention in last few years. Environmental problems, such as climate change, ozone depletion, large-scale exploitation of natural resources, and increasing contamination of air, water, and soil, increasing carbon emissions, are a continually growing concern worldwide. Degradation of environment and natural resources is happening at a rapid pace. The fact that the earth's resources are limited and are supposed to deplete soon is of utmost value. All these issues are raising numerous questions regarding protecting the environment and devising sustainable strategies. 
Industries are one of the major sections that contribute in enormous amounts to deterioration of the environment. The industrial activities that our modern world depends upon have raised atmospheric carbon dioxide levels from 280 parts per million to 412 parts per million in the last 150 years.

This scenario has fostered a new idea of consumption of goods and services which is known as the "Green Consumerism". Green Consumerism refers to a state in which consumers demand products and services that have undergone an eco-friendly production process or the one that involves recycling and safeguarding the planet's resources. (www.conserve-energy-future.com). Very fortunately, the perception of people towards goods and services has changed up to an extent today. They have become much perturbed about the goods they are consuming concerning about the environment and their own health. So, at present, it is prominent to get to the depth of knowledge consumers have about green consumerism and their willingness towards being green consumers. This study intends to make them aware about green products on the basis of their knowledge to the uttermost so that they use these products to the maximum and contribute in preventing environmental degradation by being green consumers in relation with the basic human needs i.e., food, shelter, clothing and healthcare which will ultimately help in sustainable development.

\section{Materials and Methods}

The study was conducted in Nainital district of State Uttarakhand. 120 consumers, 60 females and 60 males were selected randomly. Data were collected with the help of a developed questionnaire which consisted of different aspects of green consumerism and environmental sustainability and consumer behavior i.e. knowledge, attitude and practice.
Frequency, percentage, and correlation were used for analyzing the data statistically.

\section{Measurement of knowledge, attitude and practice}

The knowledge, attitude and practice test on green consumerism comprised of general knowledge regarding environmental hazards, green products and their role in environmental sustainability then specific details about consumers attitude towards green consumerism, practice behavior towards green consumerism and their willingness towards being green consumers. For scoring, each correct answer was assigned scores. The details of the number of questions with percentage scores about knowledge, attitude and practice are given in Table 1, Table 2 and table 3 respectively.

\section{Results and Discussion}

According to the Table 1 and Fig. 1 (62\%) of the consumers had knowledge about the fact that green products have good quality, (88\%) of the consumers considered green products good for health $(92 \%)$ of the respondents believed that green products help in protecting the environment, (96\%) believed that green products reduce global warming, (95\%) found green products organic and ecofriendly followed by (97\%) who were well aware of the fact that environmental issues are caused due to unfair means of production of goods and services.

Similarly in Table 2 and Fig. 2, that depicts the attitude of the consumers towards green consumerism, it was observed that (62\%) considered themselves eco-friendly as they favored green products over non-green products and purchased green products in spite of their high costs, (89\%) of them wanted to become green consumers by using greed products, (98\%) of the respondents 
believed that use of green products ensures clean and pollution free environment and it was remarkable that $(100 \%)$ found it really important to educate consumers about the relation between green consumerism and environmental sustainability.

Table.1 Percentage values of consumers showing consumer's knowledge on Green Consumerism and Environmental Sustainability

\begin{tabular}{|l|c|c|}
\hline Statement & $\begin{array}{c}\text { Number (out of } \\
\text { 120) }\end{array}$ & Percent \\
\hline Green products have good quality. & 75 & 62 \\
\hline Green products are good for health. & 106 & 88 \\
\hline Green products help in protecting the environment. & 111 & 92 \\
\hline $\begin{array}{l}\text { Green products reduce global warming and green } \\
\text { house gases. }\end{array}$ & 116 & 96 \\
\hline $\begin{array}{l}\text { Green products are organic and eco-friendly. } \\
\text { Environmental issues are caused due to unfair means of } \\
\text { production goods. }\end{array}$ & 114 & 95 \\
\hline
\end{tabular}

Table.2 Percentage response of respondent's attitude towards Green Consumerism and Environmental Sustainability

\begin{tabular}{|l|c|c|}
\hline Statements & Number & Percentage \\
\hline I consider myself eco-friendly as I favor green products. & 75 & 62 \\
\hline I want to be green consumer by using green products. & 107 & 89 \\
\hline I prefer green products over non-green products. & 75 & 62 \\
\hline I agree to buy green products in spite of their high price. & 75 & 62 \\
\hline $\begin{array}{l}\text { I believe that use of green products ensures clean and } \\
\text { pollution free environment. }\end{array}$ & 118 & 98 \\
\hline $\begin{array}{l}\text { I think it is important to educate consumers about the } \\
\text { relationship andween green consumerism and } \\
\text { environmental sustainability. }\end{array}$ & 120 & 100 \\
\hline
\end{tabular}

Table.3 Percentage response of consumers depicting their practice related to green consumerism

\begin{tabular}{|l|c|c|}
\hline Statements & Number & Percentage \\
\hline I prefer green products over conventional products & 75 & 62 \\
\hline I prefer green products which ensures the health of the family & 75 & 62 \\
\hline I am very much concerned about environment & 87 & 73 \\
\hline Family income affects the purchase intention of green goods & 120 & 100 \\
\hline $\begin{array}{l}\text { I prefer buying green products when price discounts are } \\
\text { offered }\end{array}$ & 75 & 62 \\
\hline I prefer buy green products even if they are expensive & 75 & 62 \\
\hline I usually buy organic food items & 71 & 59 \\
\hline
\end{tabular}


Fig.1

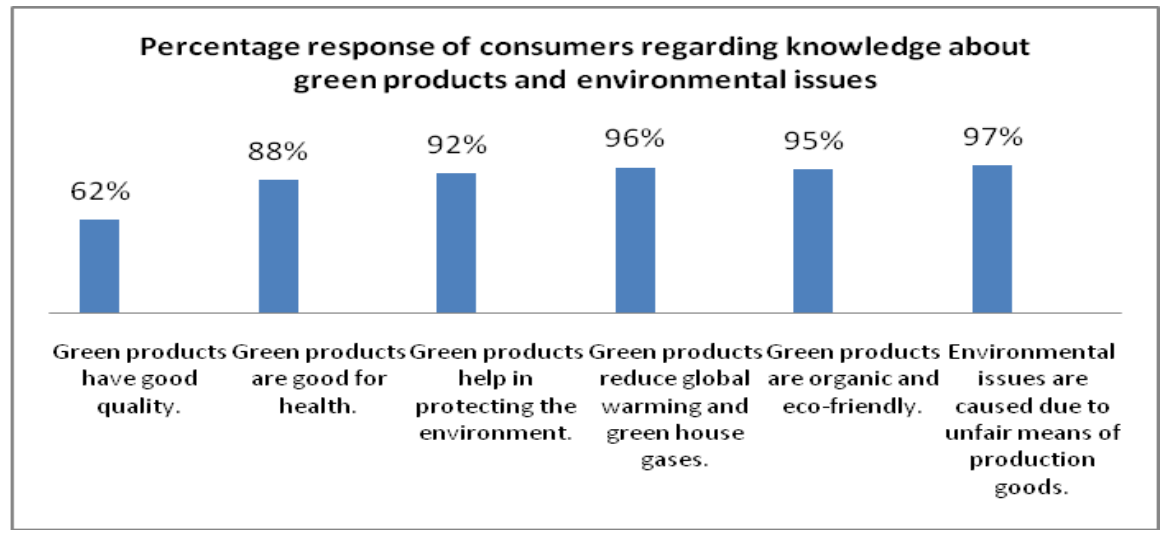

Fig.2

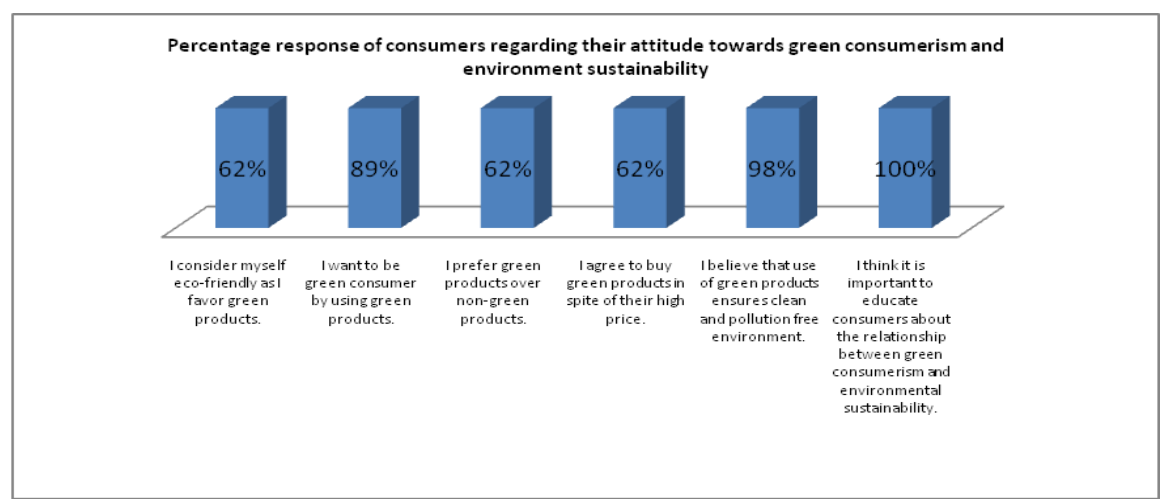

Fig.3

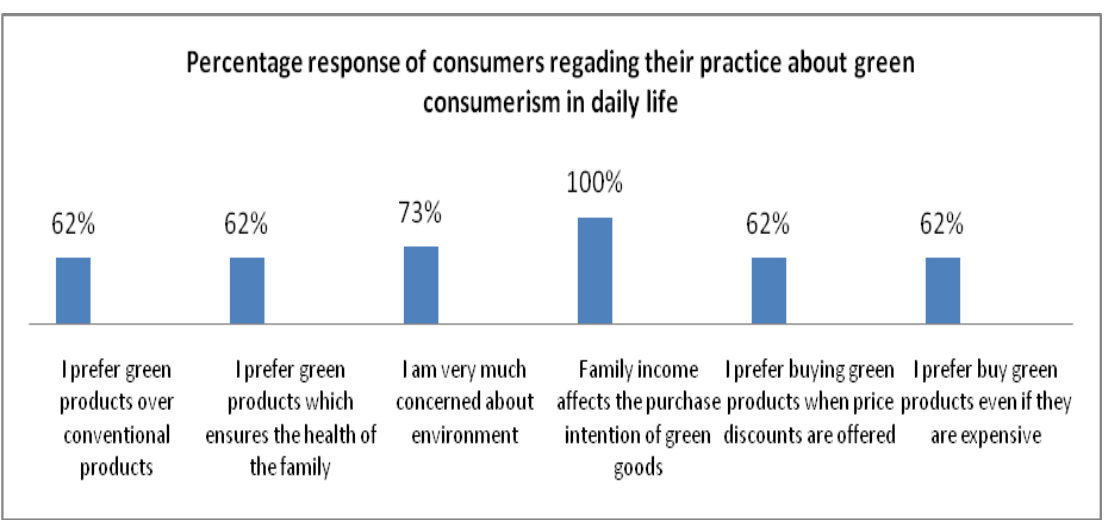

According to Table 3 and Fig. 3 (62\%) of the consumers preferred green products over conventional products and they did this so to ensure the health of their family despite of their high prices, $(73 \%)$ considered themselves concerned about the environment,
$(62 \%)$, purchased green products when price discounts were offered and (100\%) of the responded agreed to the fact that family income affects the purchase of the green products. 
As a whole it was observed that consumers had good knowledge about environmental hazards, green products and green consumerism. Positive attitude towards being green consumers were noticed and they were more willing to adopt green consumerism after knowing the accurate points about the concept and all of them agreed to the fact that it is necessary to educate consumers more.

But the restriction towards being green consumers was the high prices of green products and all of them said that family income affects the buying behavior to the utmost.

\section{References}

Article cited from (www.conserve-energyfuture.com). Retrieved on 4/4/2020.

Handayani, Wiwik. 2017. Green consumerism: an eco-friendly behavior form through green product consumption and green marketing.

Maheshwari. 2014. Various green marketing variables and their effects on consumer's buying behavior for green products.

Rahman, A. and Haliza. 2018. Components influencing the consumer behavior towards green products.

\section{How to cite this article:}

Shreya Sangwan and Rekha Vyas. 2020. Assessment of Green Consumerism on Environmental Sustainability. Int.J.Curr.Microbiol.App.Sci. 9(10): 3258-3262.

doi: https://doi.org/10.20546/ijcmas.2020.910.389 